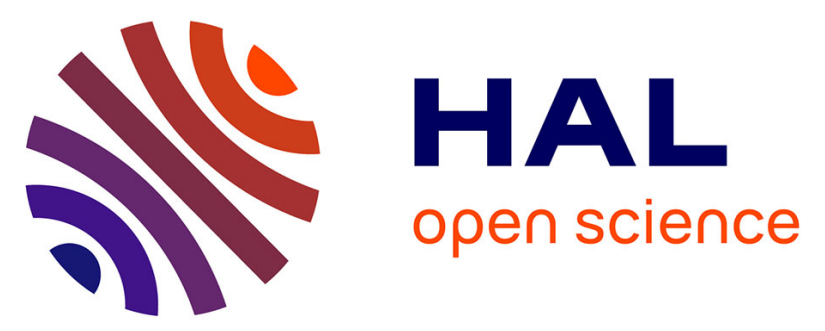

\title{
Abdominal wall morphometric variability based on computed tomography: Influence of age, gender, and body mass index
}

Arthur Jourdan, Andrea Soucasse, Ugo Scemama, Jean F Gillion, Kathia Chaumoitre, Catherine Masson, Thierry Bege

\section{To cite this version:}

Arthur Jourdan, Andrea Soucasse, Ugo Scemama, Jean F Gillion, Kathia Chaumoitre, et al.. Abdominal wall morphometric variability based on computed tomography: Influence of age, gender, and body mass index. Clinical Anatomy, 2020, 33 (8), pp.1110-1119. 10.1002/ca.23548 . hal-03226853

\section{HAL Id: hal-03226853 \\ https://hal-amu.archives-ouvertes.fr/hal-03226853}

Submitted on 15 May 2021

HAL is a multi-disciplinary open access archive for the deposit and dissemination of scientific research documents, whether they are published or not. The documents may come from teaching and research institutions in France or abroad, or from public or private research centers.
L'archive ouverte pluridisciplinaire HAL, est destinée au dépôt et à la diffusion de documents scientifiques de niveau recherche, publiés ou non, émanant des établissements d'enseignement et de recherche français ou étrangers, des laboratoires publics ou privés. 


\title{
Abdominal wall morphometric variability based on computed tomography: influence of age, sex, and BMI
}

\author{
A. Jourdan ${ }^{1, *}$, A. Soucasse ${ }^{1}$, U. Scemama ${ }^{2}$, JF. Gillion ${ }^{3}$, K. Chaumoitre ${ }^{2,4}$, C. Masson ${ }^{1}$, and T. \\ Bege $^{1,4}$; For « Club Hernie » \\ ${ }^{l}$ Laboratoire de Biomécanique Appliquée, Aix Marseille Univ, IFSTTAR UMR T24, Marseille, France \\ ${ }^{2}$ Department of Medical Imaging, Aix Marseille Univ, North Hospital, APHM, Marseille, France \\ ${ }^{3}$ Unité de Chirurgie Viscérale et Digestive, Hôpital Privé d'Antony, 1, Rue Velpeau, 92160, Antony, France \\ ${ }^{4}$ Anthropologie Biologique UMR 7268 ADES, Aix Marseille Univ, Marseille, France \\ ${ }^{5}$ Department of General Surgery, Aix Marseille Univ, North Hospital, APHM, Marseille, France
}

\begin{abstract}
Introduction: Ventral hernia surgery does not usually account for the individuality of the abdominal wall anatomy. This could be both because medical imaging is rarely performed before surgery and because data on abdominal wall variability are limited. The objective of the present study was to perform an exhaustive morphometric analysis of abdominal wall components based on computed tomography (CT) scans.

Materials and Methods: A retrospective study was performed on 120 abdominopelvic CT scans of clinically normal adults aged 18-86 y equally divided between women and men and into four age groups. Each abdominal wall muscle was evaluated in terms of area, thickness, shape ratio, fat infiltration, and aponeuroses width. The influence of age, sex, and BMI was investigated, as well as muscular asymmetry.

Results: The abdominal wall muscle area represented $8.5 \pm 2.5 \%$ of the abdominal area. The internal oblique muscle had the largest area, the rectus abdominis was the thickest, the transversus abdominis was the narrowest and had the smallest area. The width of the linea alba was $20.3 \pm 12.0 \mathrm{~mm}$. The evolution of the abdominal wall with age was quantified, as well as the large differences between the sexes and BMI groups, resulting in strong correlations and highlighting the specific pattern of the transversus abdominis. The asymmetry of the left and right muscle areas oscillated around $17 \%$.

Conclusions: The various components of the abdominal wall have been precisely described. Knowledge of their variability could be used to develop the numerical modeling of the abdominal wall to ultimately improve surgical planning of ventral hernia surgery.
\end{abstract}

Keywords: Abdominal wall ; Muscle ; Aponeurosis ; Morphometry ; Computed tomography

*Corresponding author

Contact information: Arthur Jourdan, IFSTTAR, Faculté de Médecine - Secteur Nord, Boulevard P. Dramard, 13916, Marseille

Cedex 20, France. E-mail : arthur.jourdan@ifsttar.fr. Mobile : (+33) 0615540653 , 


\section{INTRODUCTION}

Ventral hernia repair is one of the most common surgeries practiced worldwide. In France, more than 45,000 cures of acquired hernias have been carried out in 2017, and this number grew 33\% in the last 10 years (Gillion et al. 2019). In the United States, the same trend is observed and approximately 500,000 ventral hernias are repaired each year. This huge health issue corresponds to a high cost of care, estimated to be US $\$ 3.2$ billion in the United States (Miller and Novitsky 2019).

Ventral hernia is a common term for a large panel of pathologies, including both primary hernias (epigastric, umbilical, lumbar, and Spigelian) and acquired hernias (incisional and parastomal). Because of this great variety in the disease itself and because of the patient-specific composition of the abdominal wall, ventral herniation presents to surgeons a highly complex and variable problem that could explain the lack of consensus in the literature and among hernia surgeons on the ideal repair technique (Cherla et al. 2018).

Despite the improvement in hernia repair in the last two decades with the apparition of mesh repair and the laparoscopic method, the recurrence rate remains alarmingly high. Historically, primary suturing presented a high recurrence rate of 41 to $52 \%$ (Heniford et al. 2003). However, current data still show a significant recurrence rate of $28 \%$ during two-year follow-up (Gillion et al. 2019).

Surgeons face a lack of high-quality data to guide them in decision making, and this results in low agreement on a treatment strategy, even among experienced hernia surgeons (Kokotovic et al. 2017). The anatomy of the patient's abdomen is not considered when choosing a repair strategy because in most cases medical imaging is not performed before a ventral hernia repair.

In this context, our hypothesis is that the addition of quantitative morphometric knowledge of the abdominal wall would help enhance surgical planning when repairing parietal defects by adapting the technical approach and tools to each patient's specific anatomy.

A morphometric analysis of the abdominal wall can be performed precisely using CT scans. As they allow for an accurate separation of the various tissue types based on their attenuation characteristics (Mazonakis and Damilakis 2016) and an assessment of muscle properties (Engelke et al. 2018). Yet, until now, CT scans have only been used to quantify the general composition of the abdomen (Baumgartner et al. 1988) and the distribution of the fat inside it (Enzi et al. 1986). Few studies have focused on measurements that are more specific, and no analyses that account for each muscle of the abdominal wall have been conducted.

Accordingly, the purpose of this study is to present a complete morphometric analysis of the healthy abdominal wall with particular interest in the differentiation of the muscles and the aponeuroses that connect them. 


\section{MATERIALS AND METHODS}

i. Cohort's selection

A retrospective study was conducted according to the European general regulation on data protection (register RGPD/AP-HM, protocol number 2019-46) using helical abdominopelvic CT scans performed at the Imaging and Interventional Radiology Department of the North Hospital, Marseille (France) between October 2017 and April 2019.

The inclusion criteria were as follows: over 18 years old and CT scans indicated for renal colic on an outpatient basis. These criteria naturally excluded subjects with serious pathologies. We eliminated subjects meeting the following exclusion criteria: visible abdominal wall tissue disorder and the presence of serious disease (cancer, immunodeficiency).

Our radiology information system (RIS) allowed us to find 841 patients that matched inclusion criteria. In total, 120 CT scans were randomly chosen to build four age groups (18-30 y, 31-45 y, 46-60 y, and older than $60 \mathrm{y}, \mathrm{n}=$ $30 /$ group, $n=15$ women in each group), two sex groups $(n=60 /$ sex $)$, and three body mass index (BMI) groups (under and normal weight [BMI $<25, \mathrm{n}=52$ ], overweight [BMI 25-30, $\mathrm{n}=41$ ], and obese [BMI $>30, \mathrm{n}=27$ ]).

ii. $\quad$ CT Scan modalities

The scanner used was a Revolution HD GSI (GE Healthcare, USA). The protocol was identical for all patients. It consisted in one abdominopelvic acquisition without contrast injection, on patients lying supine, at their maximal inspiration. Exposure resulted in a dose of radiation of $120 \mathrm{kV}$, and the exposure time (mAS) and scan field of view varied according to the patient's weight. Slice thickness was $1.25 \mathrm{~mm}$, pitch was 1.375 , and a $40-\mathrm{mm}$ collimation was used. The obtained matrix was sized $512 \times 512$ pixels.

iii. Measurements

All CT scans were studied by the same operator (AS) using the imaging software Fiji (Open-Source) (Schindelin et al. 2012). All measurements were realized on a single axial slice located at the cranial edge of the vertebral body of the fourth lumbar vertebra. This slice level was chosen because it is a precise anatomical landmark in the L3-L4 disc region that numerous studies define as the anatomic location with the best ability to predict visceral and subcutaneous fat (Lee et al. 2004; Sottier et al. 2013; Tong et al. 2014) and core muscle size (Hasselager and Gögenur 2014).

The various geometrical measurements of adipose tissues, muscles, and muscle aponeuroses included in this study are illustrated in Figure. 1.

Waist circumference (WC) was measured as the outer perimeter of the abdomen. Subcutaneous fat thickness (SFT) was calculated as the maximum antero-posterior distance between the skin and the right rectus abdominis muscle to reproduce the measurement obtained by ultrasonography (Kanehisa et al. 2004). The abdominal area (ABA), visceral area (VA), abdominal wall muscle area (MA), subcutaneous fat area (SFA), and visceral fat area (VFA) were assessed. Fat measurement protocols for the SFA and VFA have been described in detail elsewhere (Sottier et al. 2013).

The area of every abdominal wall muscle - the rectus abdominis (RA), external oblique (EO), internal oblique (IO), and transversus abdominis (TA) - was measured for both the left and right sides. Their thicknesses were measured at their thickest point, and fat infiltration was calculated similarly to VF and expressed as a percentage of the muscle area (Anderson et al. 2013; Engelke et al. 2018). To determine whether the muscle is slender or bulky, a shape ratio was established for each muscle by dividing its maximum Feret diameter (FD, corresponding to the distance between 
the two ends of the muscle as visible in figure 1) by its thickness. The higher the shape ratio, the more slender the shape of the muscle is. The width of the linea alba (LA) was measured, along with the aponeurosis width of the three flat muscles of the abdominal wall (EO, IO, and TA), measured from the anterior end of the flat muscles to their meeting in the rectus sheath (Putz 2008).

For each measurement that was performed on the right and left sides, the value presented in the results is the mean of both sides.

iv. Muscle asymmetry

In this work, the asymmetry of the RA, TA, EO, and IO muscles was evaluated based on muscle area. The asymmetry rate was defined as the absolute difference between the sides as a percentage of the smallest value for the two sides (Mannion et al. 2008).

\section{v. Measurements accuracy}

Because the outline drawing is a fully manual intervention, measurement uncertainty was evaluated based on the inter- and intra-operator variability of the different measurements. For this, the same operator realized two times during the same week the complete analysis of five CT scans randomly chosen among the cohort. A senior radiologist (US) also realized the complete analysis of the same five CT scans. We calculated the type A measurement uncertainty based on the three values that we obtained for each measurement using the relation: $(x)=\frac{\sigma_{n-1}}{\sqrt{n}}$, where $x$ is the mean value, $\sigma_{n-1}$ is the standard-deviation, and $n$ is the number of measurements.

vi. Statistical analysis

All continuous variables were presented as mean \pm standard deviation, minimal value/maximal value, and coefficient of variation (CV, quotient of standard deviation by mean value). Differences between sex groups were tested using the Student t-test, and the analysis of variance (ANOVA) was used to compare age groups and BMI groups. A pvalue $<0.05$ indicated statistical significance.

All computations were performed with the commercially available statistical software RStudio (Version 0.98.1103, RStudio, Inc., Boston, MA).

\section{RESULTS}

i. Demographic data

The average age of the cohort is $45.7 \pm 16.7$ years old (range 18-86 y), and the average BMI was $26.1 \pm 4.9 \mathrm{~kg} / \mathrm{m}^{2}$ (range $15.6-43.3 \mathrm{~kg} / \mathrm{m}^{2}$ ).

The demographic data of each age, sex, and BMI group are presented, respectively, in Tables 1, 2, and 3.

ii. Measurements and variability

Table 1 shows the measurements and variability for the whole cohort.

The VA, MA, and SFA represent, respectively, an average $39.7 \pm 8.6 \%, 8.5 \pm 2.5 \%$, and $35.8 \pm 11.0 \%$ of the ABA, while the VFA occupies an average $50.1 \pm 17.8 \%$ of the VA. Concerning abdominal wall muscles, the IO is the biggest muscle in terms of area, and it is the least infiltrated by fat. The RA is the thickest and bulkiest muscle, while the TA is the smallest and the most slender. Muscle fat infiltration is significantly lower in the IO than in all other muscles $(\mathrm{p}<0.001)$. The average width of the LA was $20.3 \pm 12.0 \mathrm{~mm}$, and the IO had the narrowest aponeurosis $(\mathrm{p}<0.001)$. 
In terms of variability, a great variability exists between individuals, with a CV ranging from $14.1 \%$ for WC to more than $100 \%$ for muscle fat infiltration. The variability of the VA (CV 39.9\%) is much higher than that of the ABA (CV 29.6\%) and the MA (CV 29.5\%). Muscle areas and muscles thicknesses are comparable in terms of variability for each muscle (CV around 30\%), with a slightly greater variability for the EO (CV 35.8\% for muscle area and $39.8 \%$ for maximum thickness). The aponeuroses, on the other hand, show a much higher variability, ranging from $59.0 \%$ for the LA to $82.0 \%$ for the IO.

iii. Influence of age

Table 2 presents the results for the four age groups.

With age, WC $(\mathrm{p}<0.01)$, the ABA $(\mathrm{p}<0.05)$, and the VA $(\mathrm{p}<0.001)$ increased significantly. This increase was accompanied by a rise in the VFA $(\mathrm{p}<0.001)$ and fat infiltration in all muscles of the abdominal wall $(\mathrm{p}<0.001$ for the $\mathrm{RA}$ and EO, $\mathrm{p}<0.05$ for the IO, and $\mathrm{p}<0.01$ for the TA). With age, every abdominal wall muscle became thinner $(\mathrm{p}<0.001$ for the RA, $\mathrm{p}<0.05$ for the EO, and $\mathrm{p}<0.01$ for the IO) and more slender $(\mathrm{p}<0.001)$, except for the TA. The width of every aponeurosis except that for the TA increased with age ( $<<0.01$ for the LA, $p<0.001$ for the EO and $\mathrm{IO})$.

iv. Influence of sex

The overall geometry of the abdomen and particularly the abdominal wall presented a great difference between the sexes. The results for both sex groups are presented in Table 3. WC $(\mathrm{p}<0.01)$, as well as all general areas (ABA $\mathrm{p}<0.01$, VA $\mathrm{p}<0.001$, and MA $\mathrm{p}<0.001$ ), were higher in men than in women. The VFA was significantly higher in men than in women $(p<0.001)$, while both the SFT and SFA were higher in women $(p<0.05)$, which reflected a different distribution of fat according to sex. Depending on the sex, large differences in the geometry of the muscles of the abdominal wall were also observable. Every muscle presented a higher area $(p<0.001)$ and larger thickness $(\mathrm{p}<0.001)$ in men compared to women, except for the TA. The only muscle presenting a significant difference in terms of shape ratio is the TA, which is significantly bulkier in women $(\mathrm{p}<0.01)$. There is no significant difference between sexes in terms of fat infiltration for all muscles. Two aponeuroses (EO $\mathrm{p}<0.001$ and TA $\mathrm{p}<0.05)$ are significantly wider in men than in women.

v. Influence of BMI

Table 4 presents the results for the three BMI groups.

BMI is strongly correlated with WC, the ABA, the VA, the SFT, the SFA, and the VFA ( $p<0.001)$. The MA is also correlated with BMI $(\mathrm{p}<0.001)$. It is the highest in the overweight group and the lowest in the obese group. At the muscle level, this trend is also observed for the RA, EO, and IO areas. However, the TA area is the largest in the obese group. There is a significant decrease in muscle thickness with an increase in BMI for the EO $(\mathrm{p}<0.001)$ and IO $(\mathrm{p}<0.05)$. Only the RA presented a shape ratio significantly correlated with BMI, as it became more slender $(\mathrm{p}<0.01)$. Fat infiltration in every muscle is strongly correlated with BMI $(\mathrm{p}<0.001$ for the RA, IO, and TA and $\mathrm{p}<0.01$ for the EO), as well as the width of aponeuroses, all of which lengthened with an increase in BMI ( $<<0.01$ for the LA, $\mathrm{p}<0.001$ for the EO, and $\mathrm{p}<0.05$ for the IO and TA).

\section{vi. Muscle asymmetry}

Figure 2 presents the asymmetry rate for the RA, EO, IO, and TA areas.

The asymmetry rate in the whole cohort is similar for each abdominal wall muscle (RA, TA, IO, and EO), with a mean value oscillating around $17 \%$. Variability is high between individuals, where 11 individuals present a muscle asymmetry rate that is superior to $50 \%$ for at least one muscle. 
vii. $\quad$ Measurement accuracy

The calculation of type A uncertainty based on inter- and intra-operator data reveals measurement uncertainty concerning: $\pm 1.0 \mathrm{~mm}$ for WC and the SFT, $\pm 1.2 \mathrm{~cm}^{2}$ for the general and fat areas, $\pm 0.3 \mathrm{~cm}^{2}$ for the muscle areas, $\pm 0.5 \mathrm{~mm}$ for muscle thickness, $\pm 3.0 \mathrm{~mm}$ for FD, $\pm 3.7 \%$ for muscle fat infiltration, and $\pm 3.2 \mathrm{~mm}$ for aponeurosis width. 


\section{DISCUSSION}

This work, to our knowledge, is the first to provide an overall and accurate assessment of the morphometric variability of the abdominal wall. It has proven robust in various ways. Its reliability and repeatability were indicated by the good inter- and intra-operator reproducibility and by the number of strong correlations that were found and that support the conclusions presented here. In addition, the cohort built for this work is highly representative of the adult population in terms of corpulence, with $34 \%$ of the cohort being overweight and having an average slightly overweight BMI of $26.1 \mathrm{~kg} / \mathrm{m}^{2}$, a little higher in men than in women $\left(26.4-25.9 \mathrm{~kg} / \mathrm{m}^{2}\right)$, which matches French (Matta et al. 2016) and global data (WHO 2016).

Until now, morphometric studies on the abdomen have mainly involved external measures, such as WC, which has also been measured here, or sagittal abdominal diameter (2014). Medical imaging was used only to determine the general muscle and fat distribution of the abdomen. Baumgartner et al. (1988) in 1988 measured the ABA of a similar cohort using CT scans, obtaining comparable values $\left(563 \pm 145 \mathrm{~cm}^{2}\right.$ for women and $697 \pm 149 \mathrm{~cm}^{2}$ for men for, respectively, and $630 \pm 215 \mathrm{~cm}^{2}$ and $730 \pm 173 \mathrm{~cm}^{2}$ here). The few studies interested more in depth in the geometry of the abdominal wall have mainly focused on a few measurements. Ultrasound imaging was used by Kanehisa et al. (2004) to study SFT and RA thickness in a Japanese adult population: highly similar values to those presented here were found (SFT $25 \pm 10 \mathrm{~mm}$ for women $17 \pm 8 \mathrm{~mm}$ for men for, respectively, $24.2 \pm 9.0 \mathrm{~mm}$ and $20.8 \pm 8.9 \mathrm{~mm}$ here; RA thickness $9.5 \pm 2 \mathrm{~mm}$ for women and $11.5 \pm 2 \mathrm{~mm}$ for men for, respectively, $8.9 \pm 2.3 \mathrm{~mm}$ and $10.9 \pm 2.4 \mathrm{~mm}$ here). Mannion et al. (2008) also used ultrasound imaging to evaluate EO, IO, and TA thickness in healthy adult subjects and found similar values to ours (EO $6.5 \pm 2.9 \mathrm{~mm}$, IO $7.7 \pm 2.3 \mathrm{~mm}$, and TA $3.8 \pm 1.0 \mathrm{~mm}$ for, respectively, $8.0 \pm 3.2$ $\mathrm{mm}, 8.5 \pm 2.5 \mathrm{~mm}$, and $3.7 \pm 1.1 \mathrm{~mm}$ here). Punekar et al. (2018) used CT scans to measure the overlap between the RA and TA, which is not observable at the slice level chosen here. Meanwhile, Hides et al. (2008) used magnetic resonance imaging (MRI) to evaluate the core muscle area and EO and TA thickness in professional sportsmen, resulting in thicknesses almost twice as high as those presented here (IO 16.0 $\pm 3.7 \mathrm{~mm}$ and TA 7.0 $\pm 2.1 \mathrm{~mm}$ ) .

Our study confirms the great variability in the abdominal wall anatomy in the adult population. In addition, because of the depth and wide range of measurements performed in this work, it is now possible to explain this variability through the influence of age, sex, and BMI, which have been quantified and are visible in Figure 3.

The influence of age on abdominal composition was mainly based on the evolution of adipose tissue. Indeed, with age, a preferential increase in abdominal fat, particularly visceral fat, is commonly cited in the literature (Kanehisa et al. 2004; Kuk et al. 2009), which is consistent with our results. However, the influence of age on the geometry of the muscles of the abdominal wall is poorly known. Kanehisa et al. (2004), in their work, noted a decrease in RA thickness with age. This observation is confirmed here. However, it is also confirmed for the EO and IO, which were not studied in their work. In addition, it is now proven that the narrowing of these three muscles is accompanied by stretching. This modification of the muscles' geometry and the increase in intra-muscular fat observed here and commonly cited in the literature can be interpreted as an age-related loss of muscle mass, strength, and function, termed sarcopenia (Iii et al. 2000; Hasselager and Gögenur 2014). Interestingly, the loss of muscle mass is not observed for the TA, which seems preserved over the years and whose aponeurosis is the only one not to lengthen.

The sexual dimorphism observed in this study in fat distribution is in accordance with conventional notions (Enzi et al. 1986; Nedungadi and Clegg 2009). The values presented here for the VFA and SFA are in accordance with others works (Maurovich-Horvat et al. 2007; Sottier et al. 2013), yet it is hard to compare quantitative values because none of these previous works was conducted on healthy subjects. Based on whole body MRI, Janssen et al. (2000) concluded that men have significantly more skeletal muscle mass compared to women. The same trend is observed here at the muscle level. Results showed that men have the thickest abdominal wall muscles and larger muscle areas compared to women, which is consistent with the work of Kanehisa et al. (2004), who observed a thinner RA in women. Once again, there is a specificity of the TA, whose shape is bulkier in women. 
Obesity alters the muscles of the abdominal wall. It seems that the abdominal wall is more deformable anteriorly than laterally under the effect of increased visceral fat mass, as observed in figure 3 . Indeed the results presented here show that all the aponeuroses and the RA stretch substantially with the increase of the BMI, while the three flat muscles (EO, IO, and TA) maintain pretty similar sizes and shapes. This could be explained because the three flat muscles have crossed fibers orientations and so behave like a composite material (Hernández et al. 2011), resulting in a stiffer behavior of the lateral parts of the abdominal wall.

Regardless of the influence of age, sex, or BMI, the TA has been shown to have an evolution of its own. It was preserved over the years, bulkier in women and larger in obese subjects. Anatomical conventions define the TA as the "corset muscle," whose primary function is to contain viscera. Our hypothesis is that the main parameter influencing TA size is the weight of viscera. Indeed, with age and BMI, VA increases significantly, reflecting a heavier viscera mass and leading to the need for stronger muscles to contain this mass. The TA being the deepest abdominal muscle and being the only abdominal muscle with fibers running horizontally, it appears to be the muscle of the abdominal wall the most able to resist to the effort applied by the viscera. The conservation of the TA's aponeurosis width over the years could be another indicator that the TA preserves better than other abdominal wall muscles over time. Further investigation is needed to confirm this hypothesis.

Concerning muscle asymmetry, Mannion et al. (2008) determined the asymmetry of the EO, IO, and TA muscles based on their thickness, not their area. Yet, their results are extremely close to those observed here. They observed mean values for the different muscles, ranging from $11 \%$ to $26 \%$ compared with $14.8 \%$ to $18.3 \%$ here.

Of course, this study is not devoid of certain limitations. All measurements were performed on a single slice, which could limit the scope of our results. However, the slice level chosen here has been proven the most representative level of abdominal composition (Lee et al. 2004; Sottier et al. 2013; Hasselager and Gögenur 2014; Tong et al. 2014). Some anatomical structures can be difficult to identify in the setting of low-dose CT scan, with more noise than in conventional CT scan, resulting in higher measurement uncertainty. The meeting point of the flat muscles' aponeuroses and the rectus sheath can be hard to determine, resulting in significant measurement uncertainty for aponeuroses width $( \pm 3.2 \mathrm{~mm})$. Furthermore, when a poor contrast was observed on the CT scans, the common boundaries of the flat muscles (EO, IO, and TA) were sometimes difficult to identify. To reduce those biases, it was decided to present the average values of the measurements taken on both sides. In addition, the presence or absence of the umbilicus at the slice level can also change the actual width of the LA, and intermuscular fat can be considered in the calculation of muscle fat infiltration.

Despite these limitations, this study was robust and complete, and it could now be considered a reference work on abdominal wall anatomy in adults. The anatomical variability observed is certainly the witness of great variability in the mechanical properties of the tissues that constitute the abdominal wall. Knowledge of this anatomical variability may help to improve the finite element models of the abdominal wall (Hernández-Gascón et al. 2013) that have remained generic to date by making them more patient-specific. If these more bio-faithful models prove that the biomechanical behavior of the abdominal wall varies with anatomical variability, this may mean that the surgical management of ventral hernias should be personalized as well. This personalization will mainly concerns the choice of the implant material, the implant size and overlap relative to the defect size, and the fixation technique. Finally, this work allows for improvements to the realism and biofidelity of the abdominal wall surrogate models used for teaching parietal surgery (Kroese et al. 2017). Future investigations focusing on the study of the constraints applied to the abdominal wall, on the deformations of the tissues, and on establishing their biomechanical properties are necessary to deepen the conclusions presented here. 


\section{ACKNOWLEDGMENTS}

The authors have no conflicts of interest and nothing to disclose. We would like to thank Floriane Remy and Julien Mancini for their insightful comments. 


\section{REFERENCES}

Anderson DE, D'Agostino JM, Bruno AG, Demissie S, Kiel DP, Bouxsein ML. Variations of CT-Based Trunk Muscle Attenuation by Age, Sex, and Specific Muscle. J Gerontol Ser A. 2013 Mar 1;68(3):317-23.

Baumgartner RN, Heymsfield SB, Roche AF, Bernardino M. Abdominal composition quantified by computed tomography. Am J Clin Nutr. 1988 Oct 1;48(4):936-45.

Cherla DV, Poulose B, Prabhu AS. Epidemiology and Disparities in Care: The Impact of Socioeconomic Status, Gender, and Race on the Presentation, Management, and Outcomes of Patients Undergoing Ventral Hernia Repair. Surg Clin North Am. 2018 Jun 1;98(3):431-40.

Engelke K, Museyko O, Wang L, Laredo J-D. Quantitative analysis of skeletal muscle by computed tomography imaging — State of the art. J Orthop Transl. 2018 Oct 1;15:91-103.

Enzi G, Gasparo M, Biondetti PR, Fiore D, Semisa M, Zurlo F. Subcutaneous and visceral fat distribution according to sex, age, and overweight, evaluated by computed tomography. Am J Clin Nutr. 1986 Dec;44(6):739-46.

Gillion J-F, Ortega-Deballon P, Romain B. Eventrations postopératoires : Rapport présenté au 121e congrès français de chirurgie, 2019 [Internet]. 2019 [cited 2019 Jun 3]. Available from: https://www.jle.com/fr/ouvrages/edocs/eventrations_postoperatoires_313956/ouvrage.phtml

Hasselager R, Gögenur I. Core muscle size assessed by perioperative abdominal CT scan is related to mortality, postoperative complications, and hospitalization after major abdominal surgery: a systematic review. Langenbecks Arch Surg. 2014 Mar 1;399(3):287-95.

Heniford BT, Park A, Ramshaw BJ, Voeller G. Laparoscopic Repair of Ventral Hernias. Ann Surg. 2003 Sep;238(3):391-400.

Hernández B, Peña E, Pascual G, Rodríguez M, Calvo B, Doblaré M, et al. Mechanical and histological characterization of the abdominal muscle. A previous step to modelling hernia surgery. J Mech Behav Biomed Mater. 2011 Apr 1;4(3):392-404.

Hernández-Gascón B, Mena A, Peña E, Pascual G, Bellón JM, Calvo B. Understanding the Passive Mechanical Behavior of the Human Abdominal Wall. Ann Biomed Eng. 2013 Feb 1;41(2):433-44.

Hides J, Stanton W, Freke M, Wilson S, McMahon S, Richardson C. MRI study of the size, symmetry and function of the trunk muscles among elite cricketers with and without low back pain. Br J Sports Med. 2008 Oct $1 ; 42(10): 809-13$.

Iii LJM, Khosla S, Crowson CS, O’Connor MK, O’Fallon WM, Riggs BL. Epidemiology of Sarcopenia. J Am Geriatr Soc. 2000;48(6):625-30.

Janssen I, Heymsfield SB, Wang ZM, Ross R. Skeletal muscle mass and distribution in 468 men and women aged 18-88 yr. J Appl Physiol Bethesda Md 1985. 2000 Jul;89(1):81-8.

Kahn HS, Gu Q, Bullard KM, Freedman DS, Ahluwalia N, Ogden CL. Population distribution of the sagittal abdominal diameter (SAD) from a representative sample of US adults: comparison of SAD, waist circumference and body mass index for identifying dysglycemia. PloS One. 2014;9(10):e108707.

Kanehisa H, Miyatani M, Azuma K, Kuno S, Fukunaga T. Influences of age and sex on abdominal muscle and subcutaneous fat thickness. Eur J Appl Physiol. 2004 May 1;91(5):534-7.

Kokotovic D, Gögenur I, Helgstrand F. Substantial variation among hernia experts in the decision for treatment of patients with incisional hernia: a descriptive study on agreement. Hernia. 2017 Apr 1;21(2):271-8. 
Kroese LF, Harlaar JJ, Ordrenneau C, Verhelst J, Guérin G, Turquier F, et al. The 'AbdoMAN': an artificial abdominal wall simulator for biomechanical studies on laparotomy closure techniques. Hernia. 2017 Oct 1;21(5):783-91.

Kuk JL, Saunders TJ, Davidson LE, Ross R. Age-related changes in total and regional fat distribution. Ageing Res Rev. 2009 Oct 1;8(4):339-48.

Lee S, Janssen I, Ross R. Interindividual variation in abdominal subcutaneous and visceral adipose tissue: influence of measurement site. J Appl Physiol. 2004 Sep 1;97(3):948-54.

Mannion AF, Pulkovski N, Toma V, Sprott H. Abdominal muscle size and symmetry at rest and during abdominal hollowing exercises in healthy control subjects. J Anat. 2008;213(2):173-82.

Matta J, Zins M, Feral-Pierssens AL, Carette C, Ozguler A, Goldberg M, et al. Prévalence du surpoids, de l'obésité et des facteurs de risque cardio-métaboliques dans la cohorte Constances. Bull Epidémiol Hebd. 2016;(3536):640-6.

Maurovich-Horvat P, Massaro J, Fox CS, Moselewski F, O’Donnell CJ, Hoffmann U. Comparison of anthropometric, area- and volume-based assessment of abdominal subcutaneous and visceral adipose tissue volumes using multi-detector computed tomography. Int J Obes. 2007 Mar;31(3):500-6.

Mazonakis M, Damilakis J. Computed tomography: What and how does it measure? Eur J Radiol. 2016 Aug $1 ; 85(8): 1499-504$.

Miller HJ, Novitsky YW. Chapter 52 - Ventral Hernia and Abdominal Release Procedures. In: Yeo CJ, editor. Shackelford's Surgery of the Alimentary Tract, 2 Volume Set (Eighth Edition) [Internet]. Philadelphia: Content Repository Only!; 2019. p. 571-89. Available from: http://www.sciencedirect.com/science/article/pii/B9780323402323000522

Nedungadi TP, Clegg DJ. Sexual Dimorphism in Body Fat Distribution and Risk for Cardiovascular Diseases. J Cardiovasc Transl Res. 2009 Sep 1;2(3):321-7.

Punekar IRA, Khouri JS, Catanzaro M, Shaikh AL, Langstein HN. Redefining the Rectus Sheath: Implications for Abdominal Wall Repair [Internet]. 2018 [cited 2019 Jun 18]. Available from: https://www.ingentaconnect.com/content/wk/prs/2018/00000141/00000002/art00062

Putz R. Sobotta - Atlas of Human Anatomy Single Volume Edition: Head, Neck, Upper Limb, Thorax, Abdomen, Pelvis, Lower Limb. 14th ed. München: Churchill Livingstone; 2008.

Schindelin J, Arganda-Carreras I, Frise E, Kaynig V, Longair M, Pietzsch T, et al. Fiji: an open-source platform for biological-image analysis. Nat Methods. 2012 Jul;9(7):676-82.

Sottier D, Petit J-M, Guiu S, Hamza S, Benhamiche H, Hillon P, et al. Quantification of the visceral and subcutaneous fat by computed tomography: Interobserver correlation of a single slice technique. Diagn Interv Imaging. 2013 Sep 1;94(9):879-84.

Tong Y, Udupa JK, Torigian DA. Optimization of abdominal fat quantification on CT imaging through use of standardized anatomic space: A novel approach. Med Phys. 2014;41(6Part1):063501.

WHO. Overweight and obesity [Internet]. WHO. 2016 [cited 2019 Oct 16]. Available from: http://www.who.int/gho/ncd/risk_factors/overweight/en/ 
FIGURES AND TABLES (In order of citation)

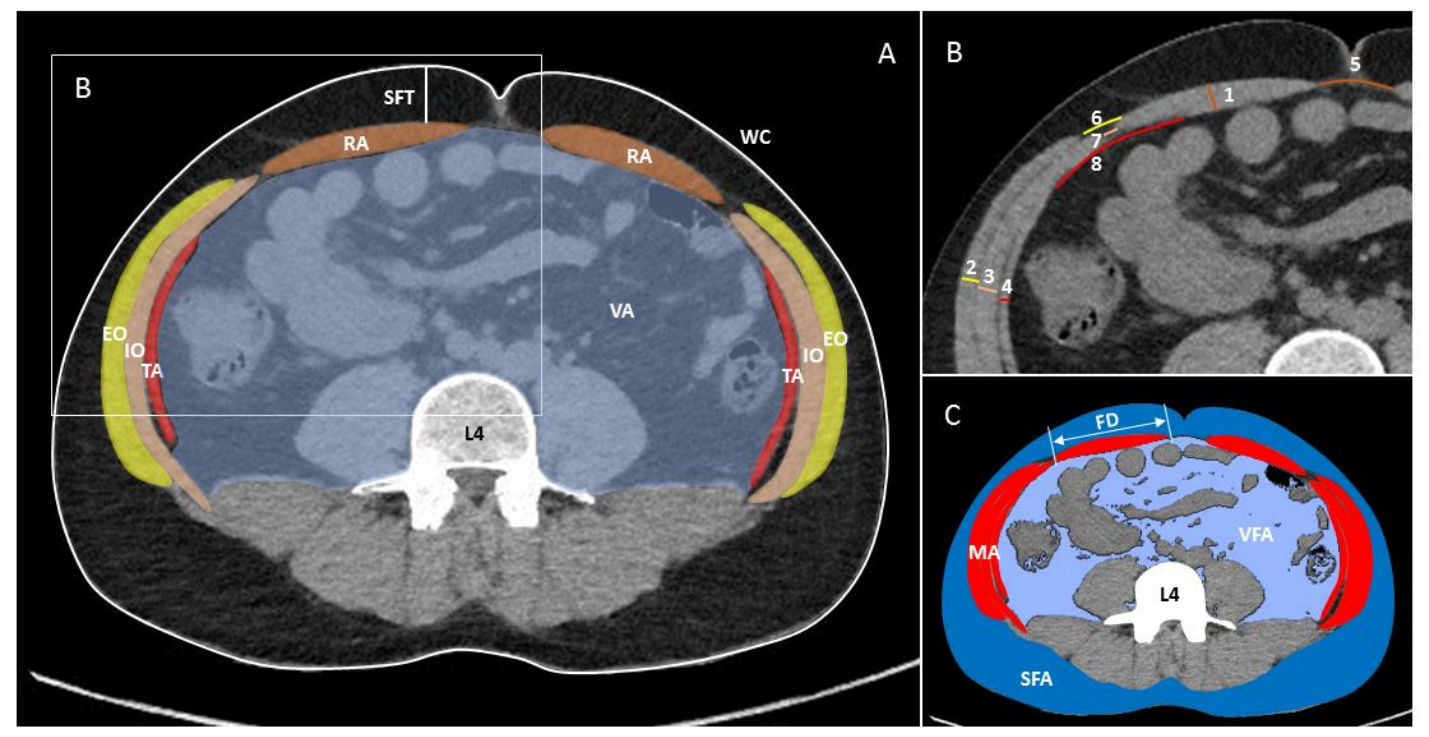

Figure 1: Details of measurements. In (b) is drawn the thickness of the RA (1), EO (2), IO (3) and TA (4), the LA (5) and the aponeuroses of the EO (6), IO (7), and TA (8). In (c) is highlighted the FD of the right RA. EO, external oblique; FD, Feret diameter; IO, internal oblique; LA, linea alba; MA, muscle area; RA, rectus abdominis; SFT, subcutaneous fat thickness; TA, transversus abdominis; VA, visceral area; VFA, visceral fat area; WC, waist circumference 


\begin{tabular}{|c|c|c|c|}
\hline Measurement & Mean & Min / Max & $\begin{array}{l}\text { Coefficient of } \\
\text { variation }(\%)\end{array}$ \\
\hline Waist circumference (WC) (mm) & 952.8 & $682.3 / 1352.9$ & 14.1 \\
\hline Subcutaneous fat thickness (SFT) (mm) & 22.5 & $3.9 / 43.5$ & 40.3 \\
\hline \multicolumn{4}{|l|}{ GENERAL AREAS $\left(\mathrm{cm}^{2}\right)$} \\
\hline Abdominal area (ABA) & 680.5 & $309.1 / 1318.4$ & 29.5 \\
\hline Visceral area (VA) & 272.2 & $87,0 / 626,0$ & 38.9 \\
\hline Abdominal wall muscle area (MA) & 55.5 & $24.4 / 102.1$ & 29.6 \\
\hline \multicolumn{4}{|l|}{ FAT AREAS $\left(\mathrm{cm}^{2}\right)$} \\
\hline Subcutaneous fat area (SFA) & 249.3 & $44.9 / 752.7$ & 50.2 \\
\hline Visceral fat area (VFA) & 149.4 & $17.2 / 449,0$ & 65.3 \\
\hline \multicolumn{4}{|l|}{ MUSCLES AREAS $\left(\mathrm{cm}^{2}\right)$} \\
\hline Rectus abdominis (RA) & 6.1 & $2,0 / 12.4$ & 31.6 \\
\hline External oblique (EO) & 8.5 & $3.5 / 17.9$ & 35.8 \\
\hline Internal oblique $(\mathrm{IO})$ & 9.4 & $4,0 / 20.5$ & 33.3 \\
\hline Transversus abdominis (TA) & 3.7 & $1.8 / 8.5$ & 33.9 \\
\hline \multicolumn{4}{|l|}{ MUSCLE THICKNESS (mm) } \\
\hline Rectus abdominis (RA) & 9.9 & $3.8 / 16.9$ & 25.6 \\
\hline External oblique (EO) & 8,0 & $2.7 / 19,0$ & 39.8 \\
\hline Internal oblique $(\mathrm{IO})$ & 8.5 & $3.6 / 16.8$ & 29.3 \\
\hline Transversus abdominis (TA) & 3.7 & $1.9 / 7.9$ & 30.3 \\
\hline \multicolumn{4}{|l|}{ SHAPE RATIO (FERET/ Thickness) } \\
\hline Rectus abdominis (RA) & 8.4 & $3.8 / 22.6$ & 42.3 \\
\hline External oblique (EO) & 18.2 & $6,0 / 54.8$ & 50.3 \\
\hline Internal oblique $(\mathrm{IO})$ & 15.7 & $5.6 / 36.7$ & 38.5 \\
\hline Transversus abdominis (TA) & 30.1 & $8.7 / 56.5$ & 35.1 \\
\hline \multicolumn{4}{|l|}{ MUSCLE FAT INFILTRATION (\%) } \\
\hline Rectus abdominis (RA) & 8.1 & $0,0 / 36.7$ & 93.9 \\
\hline External oblique (EO) & 6.4 & $0.3 / 58.8$ & 102.5 \\
\hline Internal oblique $(\mathrm{IO})$ & 1.2 & $0,0 / 10.1$ & 121.9 \\
\hline Transversus abdominis (TA) & 7.2 & $0.8 / 32.7$ & 72.6 \\
\hline \multicolumn{4}{|l|}{ APONEUROSES WIDTH (mm) } \\
\hline Linea alba (LA) & 20.3 & $3.7 / 80.9$ & 59,0 \\
\hline External oblique (EO) & 18.5 & $1.4 / 52.8$ & 52.8 \\
\hline Internal oblique $(\mathrm{IO})$ & 9.6 & $0.3 / 47,0$ & 82,0 \\
\hline Transversus abdominis (TA) & 20.3 & $0,0 / 98.6$ & 69.9 \\
\hline
\end{tabular}

Table 1. General variability 


\begin{tabular}{|c|c|c|c|c|c|c|c|c|c|}
\hline \multirow[b]{2}{*}{$\begin{array}{l}\text { DEMOGRAPHIC DATA } \\
\text { BMI }\left(\mathrm{kg} / \mathrm{m}^{2}\right) \\
\text { Men } / \text { omen }\end{array}$} & \multicolumn{2}{|c|}{$\begin{array}{l}\text { Age group } 1 \\
(18-30 \mathrm{yr}) \\
n=30\end{array}$} & \multicolumn{2}{|c|}{$\begin{array}{c}\text { Age group } 2 \\
(31-45 \mathrm{yr}) \\
n=30\end{array}$} & \multicolumn{2}{|c|}{$\begin{array}{c}\text { Age group } 3 \\
\text { (46-60 yr) } \\
n=30\end{array}$} & \multicolumn{2}{|c|}{$\begin{array}{c}\text { Age group } 4 \\
(>60 \mathrm{yr}) \\
n=30\end{array}$} & \\
\hline & \multicolumn{2}{|c|}{$\begin{aligned} & 26,0 \pm 5.5 \\
& 15 / 15 \\
&\end{aligned}$} & \multicolumn{2}{|c|}{$\begin{aligned} & 25.2 \pm 5.6 \\
& 15 / 15 \\
&\end{aligned}$} & \multicolumn{2}{|c|}{$\begin{aligned} & 27.4 \pm 4.4 \\
& 15 / 15 \\
&\end{aligned}$} & \multicolumn{2}{|c|}{$\begin{aligned} & 25.9 \pm 4,0 \\
& 15 / 15 \\
&\end{aligned}$} & \multirow[b]{2}{*}{ p-value } \\
\hline Measurement & Mean & CV $(\%)$ & Mean & CV $(\%)$ & Mean & CV $(\%)$ & Mean & CV (\%) & \\
\hline $\begin{array}{l}\text { Waist circumference }(W C)(\mathrm{mm}) \\
\text { Subcutaneous fat thickness (SFT) (mm) }\end{array}$ & $\begin{array}{r}909.7 \\
21.5\end{array}$ & $\begin{array}{l}17,0 \\
46.3\end{array}$ & $\begin{array}{r}912.9 \\
22.1\end{array}$ & $\begin{array}{l}14.8 \\
37.6\end{array}$ & $\begin{array}{r}993.1 \\
25.1\end{array}$ & $\begin{array}{l}10,0 \\
29.9\end{array}$ & $\begin{array}{r}995.4 \\
21.3\end{array}$ & $\begin{array}{l}12.3 \\
47.8\end{array}$ & $\begin{array}{l}0.008 \\
0.345\end{array}$ \\
\hline \multicolumn{10}{|l|}{ GENERAL AREAS $\left(\mathrm{cm}^{2}\right)$} \\
\hline $\begin{array}{l}\text { Abdominal area (ABA) } \\
\text { Visceral area (VA) } \\
\text { Abdominal wall muscle area (MA) }\end{array}$ & $\begin{array}{r}624.6 \\
218.4 \\
56.3\end{array}$ & $\begin{array}{l}36.1 \\
37.6 \\
31.5\end{array}$ & $\begin{array}{r}618.4 \\
225.7 \\
56.7\end{array}$ & $\begin{array}{l}31.8 \\
29.5 \\
29.3\end{array}$ & $\begin{array}{r}736.6 \\
309.2 \\
57.6\end{array}$ & $\begin{array}{l}21.7 \\
30.8 \\
29.8\end{array}$ & $\begin{array}{r}742.4 \\
335.6 \\
51.7\end{array}$ & $\begin{array}{l}25.6 \\
36.3 \\
27.4\end{array}$ & $\begin{array}{c}0.014 \\
p<0.001 \\
0.511\end{array}$ \\
\hline \multicolumn{10}{|l|}{ FAT AREAS $\left(\mathrm{cm}^{2}\right)$} \\
\hline $\begin{array}{l}\text { Subcutaneous fat area (SFA) } \\
\text { Visceral fat area (VFA) }\end{array}$ & $\begin{array}{l}249.5 \\
101.6\end{array}$ & $\begin{array}{l}57.9 \\
68.9\end{array}$ & $\begin{array}{r}234,0 \\
99,0\end{array}$ & $\begin{array}{l}57.9 \\
65.1\end{array}$ & $\begin{array}{l}261.7 \\
181.8\end{array}$ & $\begin{array}{l}32.9 \\
47.9\end{array}$ & $\begin{array}{l}251.9 \\
215.1\end{array}$ & $\begin{array}{l}52.2 \\
50.6\end{array}$ & $\begin{array}{c}0.864 \\
p<0.001\end{array}$ \\
\hline \multicolumn{10}{|l|}{ MUSCLES AREAS $\left(\mathrm{cm}^{2}\right)$} \\
\hline $\begin{array}{l}\text { Rectus abdominis (RA) } \\
\text { External oblique (EO) } \\
\text { Internal oblique (IO) } \\
\text { Transversus abdominis (TA) }\end{array}$ & $\begin{array}{l}6.1 \\
9.2 \\
9.8 \\
3,0\end{array}$ & $\begin{array}{l}23.6 \\
36.3 \\
38.3 \\
35.7\end{array}$ & $\begin{array}{l}6.4 \\
8.6 \\
9.8 \\
3.5\end{array}$ & $\begin{array}{l}32.3 \\
36.8 \\
29.3 \\
25.7\end{array}$ & $\begin{array}{l}6.3 \\
8.8 \\
9.3 \\
4.4\end{array}$ & $\begin{array}{l}34.5 \\
33.2 \\
36.5 \\
33.8\end{array}$ & $\begin{array}{l}5.5 \\
7.5 \\
8.7 \\
4,0\end{array}$ & $\begin{array}{l}34.7 \\
35.4 \\
27.2 \\
29,0\end{array}$ & $\begin{array}{c}0.297 \\
0.19 \\
0.47 \\
p<0.001\end{array}$ \\
\hline \multicolumn{10}{|l|}{ MUSCLE THICKNESS (mm) } \\
\hline $\begin{array}{l}\text { Rectus abdominis (RA) } \\
\text { External oblique (EO) } \\
\text { Internal oblique (IO) } \\
\text { Transversus abdominis (TA) }\end{array}$ & $\begin{array}{r}10.9 \\
9.3 \\
9.4 \\
3.3\end{array}$ & $\begin{array}{l}15.8 \\
30.7 \\
28.4 \\
28.7\end{array}$ & $\begin{array}{r}10.8 \\
8,0 \\
9.1 \\
3.7\end{array}$ & $\begin{array}{l}23.3 \\
43.5 \\
26.6 \\
28.5\end{array}$ & $\begin{array}{l}9.5 \\
7.8 \\
7.9 \\
4,0\end{array}$ & $\begin{array}{l}23.8 \\
35.7 \\
30.6 \\
34.4\end{array}$ & $\begin{array}{l}8.3 \\
6.8 \\
7.6 \\
3.9\end{array}$ & $\begin{array}{l}31.5 \\
46.5 \\
26.7 \\
26.6\end{array}$ & $\begin{array}{l}p<0.001 \\
0.021 \\
0.008 \\
0.137\end{array}$ \\
\hline \multicolumn{10}{|l|}{ SHAPE RATIO (FERET/ Thickness) } \\
\hline $\begin{array}{l}\text { Rectus abdominis (RA) } \\
\text { External oblique (EO) } \\
\text { Internal oblique (IO) } \\
\text { Transversus abdominis (TA) }\end{array}$ & $\begin{array}{r}6.4 \\
12.7 \\
12.6 \\
28.7\end{array}$ & $\begin{array}{l}31.8 \\
27.8 \\
32.1 \\
31.8\end{array}$ & $\begin{array}{r}6.9 \\
16.6 \\
13.5 \\
28,0\end{array}$ & $\begin{array}{l}25.6 \\
37.7 \\
28.7 \\
32.7\end{array}$ & $\begin{array}{r}8.8 \\
20,0 \\
17.7 \\
32.4\end{array}$ & $\begin{array}{l}24.7 \\
44.2 \\
35.7 \\
37.5\end{array}$ & $\begin{array}{l}11.3 \\
23.7 \\
18.9 \\
31.4\end{array}$ & $\begin{array}{l}43.2 \\
51.4 \\
36.8 \\
36.2\end{array}$ & $\begin{array}{l}p<0.001 \\
p<0.001 \\
p<0.001 \\
0.299\end{array}$ \\
\hline \multicolumn{10}{|l|}{ MUSCLE FAT INFILTRATION (\%) } \\
\hline $\begin{array}{l}\text { Rectus abdominis (RA) } \\
\text { External oblique (EO) } \\
\text { Internal oblique (IO) } \\
\text { Transversus abdominis (TA) }\end{array}$ & $\begin{array}{l}5,0 \\
4.3 \\
0.9 \\
6,0\end{array}$ & $\begin{array}{c}84.1 \\
56.2 \\
103,0 \\
82.3\end{array}$ & $\begin{array}{l}6.6 \\
4.4 \\
0.8 \\
5.2\end{array}$ & $\begin{array}{c}105.3 \\
59.1 \\
120.7 \\
66.5\end{array}$ & $\begin{array}{r}12.7 \\
6.6 \\
1.5 \\
8.3\end{array}$ & $\begin{array}{c}75.7 \\
54.7 \\
135,0 \\
48.2\end{array}$ & $\begin{array}{r}8.2 \\
10.3 \\
1.7 \\
9.2\end{array}$ & $\begin{array}{c}82,0 \\
109.3 \\
95,0 \\
75.1\end{array}$ & $\begin{array}{l}p<0.001 \\
p<0.001 \\
0.033 \\
0.007\end{array}$ \\
\hline \multicolumn{10}{|l|}{ APONEUROSES WIDTH $(\mathrm{mm})$} \\
\hline $\begin{array}{l}\text { Linea alba (LA) } \\
\text { External oblique (EO) } \\
\text { Internal oblique (IO) } \\
\text { Transversus abdominis (TA) }\end{array}$ & $\begin{array}{r}16.6 \\
16.8 \\
6.3 \\
20.9\end{array}$ & $\begin{array}{l}60.9 \\
46.4 \\
72.8 \\
56.1\end{array}$ & $\begin{array}{r}16.4 \\
13.9 \\
6.3 \\
17.4\end{array}$ & $\begin{array}{l}51.5 \\
53.1 \\
59.7 \\
64.9\end{array}$ & $\begin{array}{l}24.3 \\
18.8 \\
11.1 \\
18.6\end{array}$ & $\begin{array}{l}39.3 \\
44.3 \\
49.7 \\
94.5\end{array}$ & $\begin{array}{l}24,0 \\
24.5 \\
14.8 \\
24.4\end{array}$ & $\begin{array}{l}67.8 \\
49.2 \\
79,0 \\
61.4\end{array}$ & $\begin{array}{c}0.006 \\
p<0.001 \\
p<0.001 \\
0.24\end{array}$ \\
\hline
\end{tabular}

$\mathrm{CV}=$ Coefficient of variation

Table 2. Influence of age 


\begin{tabular}{|c|c|c|c|c|c|}
\hline \multirow{3}{*}{$\begin{array}{l}\text { DEMOGRAPHIC DATA } \\
\text { Age } \\
\text { BMI }\left(\mathrm{kg} / \mathrm{m}^{2}\right) \\
\text { Measurement }\end{array}$} & \multicolumn{2}{|c|}{$\begin{array}{c}\text { Women } \\
\mathrm{n}=60\end{array}$} & \multicolumn{2}{|c|}{$\begin{array}{l}\text { Men } \\
\mathrm{n}=60\end{array}$} & \multirow[b]{3}{*}{ p-value } \\
\hline & \multicolumn{2}{|c|}{$\begin{array}{l}45.1 \pm 17.2 \\
25.9 \pm 5.7\end{array}$} & \multicolumn{2}{|c|}{$\begin{array}{l}46.4 \pm 16.2 \\
26.4 \pm 4,0 \\
\end{array}$} & \\
\hline & Mean & CV (\%) & Mean & CV (\%) & \\
\hline $\begin{array}{l}\text { Waist circumference (WC) (mm) } \\
\text { Subcutaneous fat thickness (SFT) (mm) }\end{array}$ & $\begin{array}{r}920.2 \\
24.2\end{array}$ & $\begin{array}{l}15.8 \\
37.2\end{array}$ & $\begin{array}{r}985.4 \\
20.8\end{array}$ & $\begin{array}{l}11.6 \\
42.7\end{array}$ & $\begin{array}{l}0.007 \\
0.039\end{array}$ \\
\hline \multicolumn{6}{|l|}{ GENERAL AREAS $\left(\mathrm{cm}^{2}\right)$} \\
\hline $\begin{array}{l}\text { Abdominal area (ABA) } \\
\text { Visceral area (VA) } \\
\text { Abdominal wall muscle area (MA) }\end{array}$ & $\begin{array}{r}630.3 \\
222.9 \\
43.9\end{array}$ & $\begin{array}{l}34.1 \\
37.2 \\
20.3\end{array}$ & $\begin{array}{r}730.6 \\
321.5 \\
67.2\end{array}$ & $\begin{array}{l}23.8 \\
32.2 \\
20.4\end{array}$ & $\begin{array}{l}0.006 \\
p<0.001 \\
p<0.001\end{array}$ \\
\hline \multicolumn{6}{|l|}{ FAT AREAS $\left(\mathrm{cm}^{2}\right)$} \\
\hline $\begin{array}{l}\text { Subcutaneous fat area (SFA) } \\
\text { Visceral fat area (VFA) }\end{array}$ & $\begin{array}{l}274.1 \\
108.3\end{array}$ & $\begin{array}{l}51.5 \\
74.1\end{array}$ & $\begin{array}{l}224.4 \\
190.4\end{array}$ & $\begin{array}{l}45.6 \\
50.7\end{array}$ & $\begin{array}{c}0.029 \\
p<0.001\end{array}$ \\
\hline \multicolumn{6}{|l|}{ MUSCLES AREAS $\left(\mathrm{cm}^{2}\right)$} \\
\hline $\begin{array}{l}\text { Rectus abdominis (RA) } \\
\text { External oblique (EO) } \\
\text { Internal oblique (IO) } \\
\text { Transversus abdominis (TA) }\end{array}$ & $\begin{array}{l}5,0 \\
6.6 \\
7.3 \\
3.1\end{array}$ & $\begin{array}{l}27.9 \\
26.5 \\
22.5 \\
28.1\end{array}$ & $\begin{array}{r}7.3 \\
10.5 \\
11.5 \\
4.3\end{array}$ & $\begin{array}{l}23.7 \\
26.8 \\
24.7 \\
29.9\end{array}$ & $\begin{array}{l}p<0.001 \\
p<0.001 \\
p<0.001 \\
p<0.001\end{array}$ \\
\hline \multicolumn{6}{|l|}{ MUSCLE THICKNESS (mm) } \\
\hline $\begin{array}{l}\text { Rectus abdominis (RA) } \\
\text { External oblique (EO) } \\
\text { Internal oblique (IO) } \\
\text { Transversus abdominis (TA) }\end{array}$ & $\begin{array}{l}8.9 \\
7,0 \\
7.7 \\
3.6\end{array}$ & $\begin{array}{l}25.9 \\
36.1 \\
28.5 \\
30.7\end{array}$ & $\begin{array}{r}10.9 \\
9,0 \\
9.3 \\
3.8\end{array}$ & $\begin{array}{l}21.7 \\
38.4 \\
27.2 \\
29.9\end{array}$ & $\begin{array}{l}p<0.001 \\
p<0.001 \\
p<0.001 \\
0.349\end{array}$ \\
\hline \multicolumn{6}{|l|}{ SHAPE RATIO (FERET/ Thickness) } \\
\hline $\begin{array}{l}\text { Rectus abdominis (RA) } \\
\text { External oblique (EO) } \\
\text { Internal oblique (IO) } \\
\text { Transversus abdominis (TA) }\end{array}$ & $\begin{array}{r}8.6 \\
18.1 \\
15.1 \\
27.4\end{array}$ & $\begin{array}{l}44.9 \\
46.4 \\
37.4 \\
33.6\end{array}$ & $\begin{array}{r}8.1 \\
18.4 \\
16.3 \\
32.8\end{array}$ & $\begin{array}{l}39.4 \\
54.2 \\
39.3 \\
34.1\end{array}$ & $\begin{array}{l}0.448 \\
0.831 \\
0.279 \\
0.005\end{array}$ \\
\hline \multicolumn{6}{|l|}{ MUSCLE FAT INFILTRATION (\%) } \\
\hline $\begin{array}{l}\text { Rectus abdominis (RA) } \\
\text { External oblique (EO) } \\
\text { Internal oblique (IO) } \\
\text { Transversus abdominis (TA) }\end{array}$ & $\begin{array}{l}8.6 \\
6.2 \\
1.1 \\
7.3\end{array}$ & $\begin{array}{c}97.9 \\
123.6 \\
125.5 \\
79.5\end{array}$ & $\begin{array}{l}7.6 \\
6.6 \\
1.3 \\
7.1\end{array}$ & $\begin{array}{c}88.3 \\
80,0 \\
118.9 \\
64.9\end{array}$ & $\begin{array}{c}0.45 \\
0.758 \\
0.443 \\
0.789\end{array}$ \\
\hline \multicolumn{6}{|l|}{ APONEUROSES WIDTH (mm) } \\
\hline Linea alba (LA) & 22,0 & 64.8 & 18.7 & 48.4 & 0.134 \\
\hline External oblique (EO) & 15.1 & 62,0 & 21.9 & 41.2 & $p<0.001$ \\
\hline Internal oblique (10) & 9.4 & 83.6 & 9.9 & 80.9 & 0.704 \\
\hline Transversus abdominis (TA) & 17.6 & 68.9 & 23,0 & 67.9 & 0.035 \\
\hline
\end{tabular}

Table 3. Influence of sex 


\begin{tabular}{|c|c|c|c|c|c|c|c|}
\hline \multirow{3}{*}{$\begin{array}{l}\text { DEMOGRAPHIC DATA } \\
\text { Age }\left(\mathrm{kg} / \mathrm{m}^{2}\right) \\
\text { Men } N \text { Nomen } \\
\text { Measurement }\end{array}$} & \multicolumn{2}{|c|}{$\begin{array}{c}\begin{array}{c}\text { Under and normal weight } \\
(B M I<25) \\
n=52\end{array} \\
\end{array}$} & \multicolumn{2}{|c|}{$\begin{array}{c}\text { Overweight } \\
\text { (BMI 25-30) } \\
n=41 \\
\end{array}$} & \multicolumn{2}{|c|}{$\begin{array}{c}\text { Obese } \\
(\mathrm{BMI}>30) \\
\mathrm{n}=27\end{array}$} & \multirow[b]{3}{*}{ p-value } \\
\hline & \multicolumn{2}{|c|}{$\begin{aligned} & 41.1 \pm 15.1 \\
& 31 / 21 \\
&\end{aligned}$} & \multicolumn{2}{|c|}{$\begin{aligned} & 51.3 \pm 17.2 \\
& 15 / 26 \\
&\end{aligned}$} & \multicolumn{2}{|c|}{$\begin{aligned} & 45.7 \pm 15.1 \\
& 14 / 13 \\
&\end{aligned}$} & \\
\hline & Mean & CV (\%) & Mean & CV (\%) & Mean & CV (\%) & \\
\hline $\begin{array}{l}\text { Waist circumference (WC) (mm) } \\
\text { Subcutaneous fat thickness (SFT) (mm) }\end{array}$ & $\begin{array}{r}846.2 \\
18.2\end{array}$ & $\begin{array}{l}10.5 \\
39.5\end{array}$ & $\begin{array}{r}987,0 \\
22,0\end{array}$ & $\begin{array}{l}7,0 \\
35.8\end{array}$ & $\begin{array}{r}1106.1 \\
31.7\end{array}$ & $\begin{array}{l}9.4 \\
23.3\end{array}$ & $\begin{array}{l}p<0.001 \\
p<0.001\end{array}$ \\
\hline \multicolumn{8}{|l|}{ GENERAL AREAS $\left(\mathrm{cm}^{2}\right)$} \\
\hline $\begin{array}{l}\text { Abdominal area (ABA) } \\
\text { Visceral area (VA) } \\
\text { Abdominal wall muscle area (MA) }\end{array}$ & $\begin{array}{r}524.6 \\
213.3 \\
54.8\end{array}$ & $\begin{array}{l}21.9 \\
33.4 \\
31.1\end{array}$ & $\begin{array}{r}722.2 \\
302.9 \\
58,0\end{array}$ & $\begin{array}{l}15.3 \\
37.4 \\
29.1\end{array}$ & $\begin{array}{r}917.5 \\
339.1 \\
53,0\end{array}$ & $\begin{array}{l}19.1 \\
27,0 \\
26.8\end{array}$ & $\begin{array}{l}p<0.001 \\
p<0.001 \\
p<0.001\end{array}$ \\
\hline \multicolumn{8}{|l|}{ FAT AREAS $\left(\mathrm{cm}^{2}\right)$} \\
\hline $\begin{array}{l}\text { Subcutaneous fat area (SFA) } \\
\text { Visceral fat area (VFA) }\end{array}$ & $\begin{array}{r}170.5 \\
86.5\end{array}$ & $\begin{array}{l}39.3 \\
70,0\end{array}$ & $\begin{array}{l}251.8 \\
183.4\end{array}$ & $\begin{array}{l}30.5 \\
53.5\end{array}$ & $\begin{array}{l}397.2 \\
218.7\end{array}$ & $\begin{array}{l}34.5 \\
37.8\end{array}$ & $\begin{array}{l}p<0.001 \\
p<0.001\end{array}$ \\
\hline \multicolumn{8}{|l|}{ MUSCLES AREAS $\left(\mathrm{cm}^{2}\right)$} \\
\hline $\begin{array}{l}\text { Rectus abdominis (RA) } \\
\text { External oblique (EO) } \\
\text { Internal oblique (IO) } \\
\text { Transversus abdominis (TA) }\end{array}$ & $\begin{array}{l}6.1 \\
8.6 \\
9.6 \\
3.1\end{array}$ & $\begin{array}{l}28.3 \\
37.6 \\
35.1 \\
31.1\end{array}$ & $\begin{array}{l}6.4 \\
9,0 \\
9.5 \\
4.1\end{array}$ & $\begin{array}{l}33.8 \\
33.3 \\
34.5 \\
33.2\end{array}$ & $\begin{array}{l}5.7 \\
7.7 \\
8.9 \\
4.2\end{array}$ & $\begin{array}{l}34.3 \\
35.4 \\
27,0 \\
27.6\end{array}$ & $\begin{array}{l}p<0.001 \\
0.001 \\
p<0.001 \\
p<0.001\end{array}$ \\
\hline \multicolumn{8}{|l|}{ MUSCLE THICKNESS (mm) } \\
\hline $\begin{array}{l}\text { Rectus abdominis (RA) } \\
\text { External oblique (EO) } \\
\text { Internal oblique (IO) } \\
\text { Transversus abdominis (TA) }\end{array}$ & $\begin{array}{r}10.8 \\
8.5 \\
9.2 \\
3.5\end{array}$ & $\begin{array}{l}19.9 \\
37.5 \\
28.4 \\
29.9\end{array}$ & $\begin{array}{l}9.7 \\
8.1 \\
8.2 \\
3.9\end{array}$ & $\begin{array}{l}25.2 \\
37.1 \\
28.8 \\
33.3\end{array}$ & $\begin{array}{l}8.4 \\
6.9 \\
7.6 \\
3.9\end{array}$ & $\begin{array}{l}31.6 \\
47.6 \\
27.8 \\
23.8\end{array}$ & $\begin{array}{c}0.84 \\
0.021 \\
0.039 \\
0.264\end{array}$ \\
\hline \multicolumn{8}{|l|}{ SHAPE RATIO (FERET/ Thickness) } \\
\hline $\begin{array}{l}\text { Rectus abdominis (RA) } \\
\text { External oblique (EO) } \\
\text { Internal oblique (IO) } \\
\text { Transversus abdominis (TA) }\end{array}$ & $\begin{array}{r}6.7 \\
14.8 \\
13,0 \\
28.3\end{array}$ & $\begin{array}{l}30.5 \\
36.9 \\
31.2 \\
31.9\end{array}$ & $\begin{array}{r}8.5 \\
18.8 \\
16.6 \\
31.4\end{array}$ & $\begin{array}{l}27.4 \\
45.6 \\
35.4 \\
37.8\end{array}$ & $\begin{array}{l}11.4 \\
24,0 \\
19.4 \\
31.7\end{array}$ & $\begin{array}{l}44.2 \\
52,0 \\
37,0 \\
35,0\end{array}$ & $\begin{array}{l}0.002 \\
0.854 \\
0.682 \\
0.482\end{array}$ \\
\hline \multicolumn{8}{|l|}{ MUSCLE FAT INFILTRATION (\%) } \\
\hline $\begin{array}{l}\text { Rectus abdominis (RA) } \\
\text { External oblique (EO) } \\
\text { Internal oblique (IO) } \\
\text { Transversus abdominis (TA) }\end{array}$ & $\begin{array}{l}5.8 \\
4.3 \\
0.9 \\
5.8\end{array}$ & $\begin{array}{l}95.2 \\
57.7 \\
106,0 \\
77.9\end{array}$ & $\begin{array}{r}10.8 \\
6.1 \\
1.3 \\
7.4\end{array}$ & $\begin{array}{l}86.2 \\
56.5 \\
140.6 \\
52.5\end{array}$ & $\begin{array}{r}8.5 \\
10.8 \\
1.8 \\
9.6\end{array}$ & $\begin{array}{l}82.8 \\
108.9 \\
94.8 \\
74.8\end{array}$ & $\begin{array}{l}p<0.001 \\
0.001 \\
p<0.001 \\
p<0.001\end{array}$ \\
\hline \multicolumn{8}{|l|}{ APONEUROSES WIDTH (mm) } \\
\hline $\begin{array}{l}\text { Linea alba (LA) } \\
\text { External oblique (EO) } \\
\text { Internal oblique (IO) } \\
\text { Transversus abdominis (TA) }\end{array}$ & $\begin{array}{r}17.9 \\
15.3 \\
6.3 \\
19.1 \\
\end{array}$ & $\begin{array}{l}69.7 \\
52.9 \\
67.4 \\
61.5\end{array}$ & $\begin{array}{r}19,0 \\
17.7 \\
9.8 \\
18.3 \\
\end{array}$ & $\begin{array}{l}49,0 \\
43.5 \\
55.1 \\
86.4 \\
\end{array}$ & $\begin{array}{l}27,0 \\
25.9 \\
15.7 \\
25.8 \\
\end{array}$ & $\begin{array}{l}46.6 \\
45.6 \\
76.3 \\
58.6 \\
\end{array}$ & $\begin{array}{c}0.003 \\
p<0.001 \\
0.037 \\
0.045 \\
\end{array}$ \\
\hline
\end{tabular}

Table 4. Influence of BMI 


\section{Asymmetry of abdominal wall muscles}

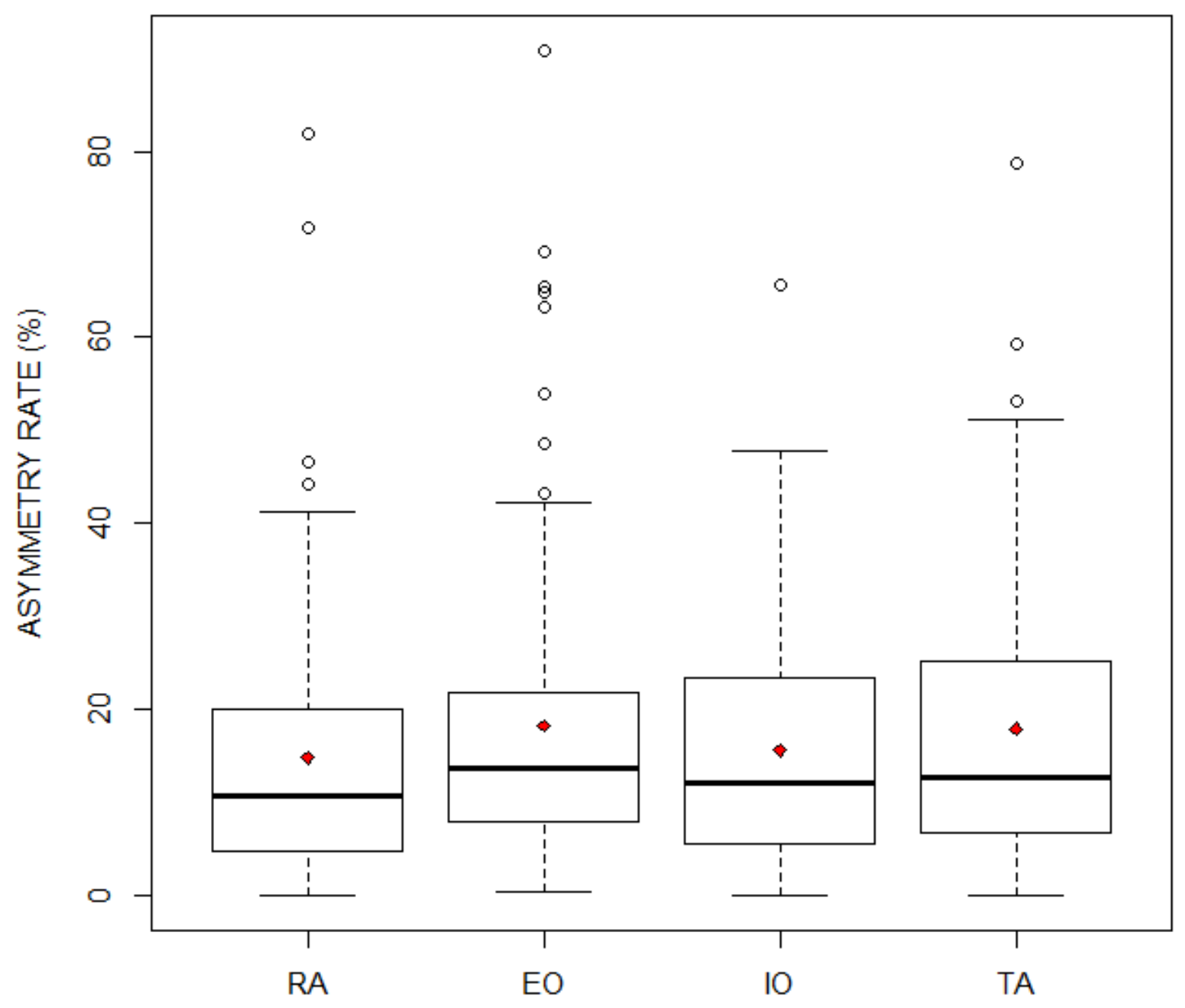

Figure 2. The asymmetry rate of the four abdominal wall muscles. The red dots represent the mean value. 

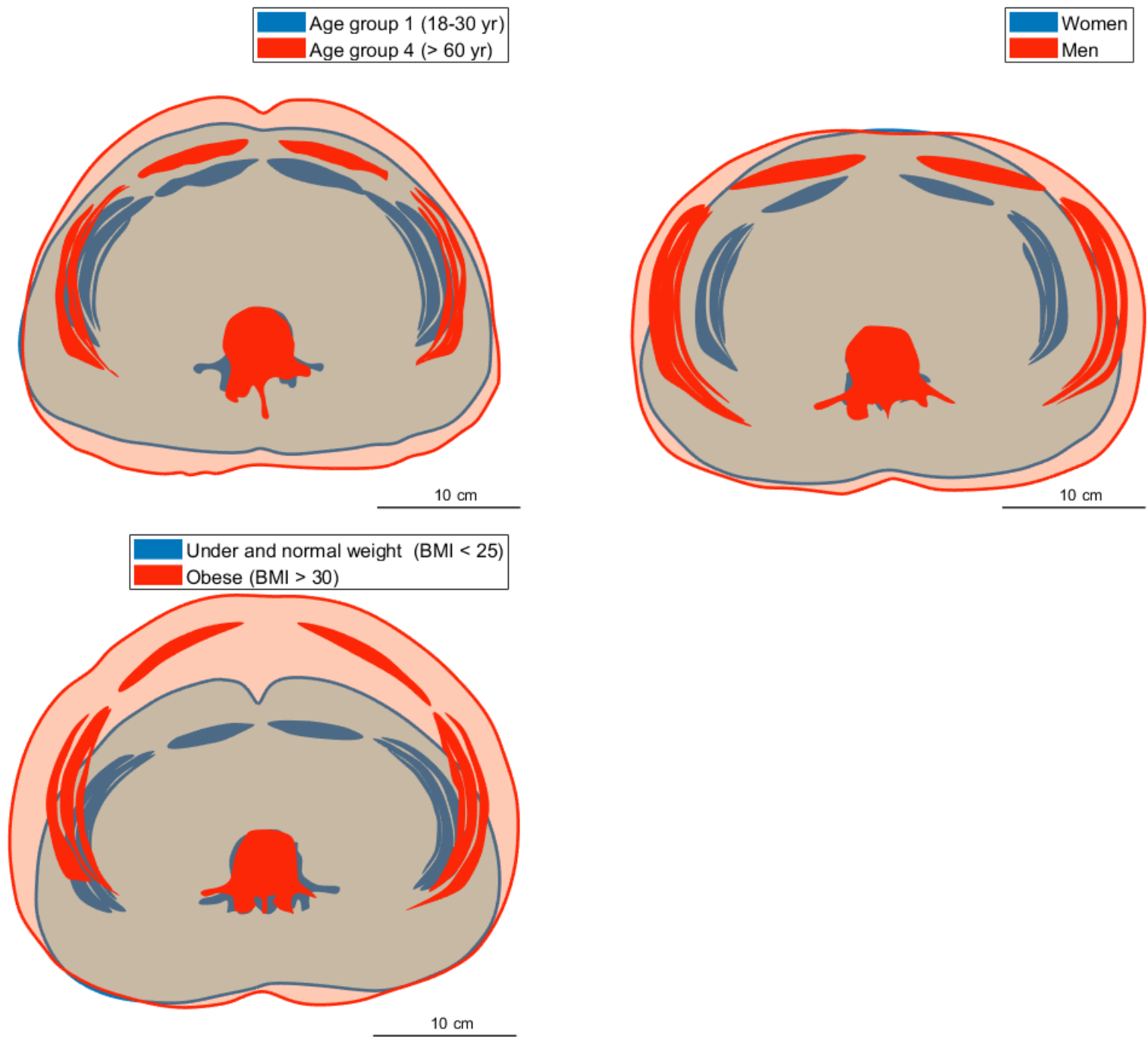

Figure 3. Comparison of the geometry of the abdominal wall muscles of the most representative subjects (determined on the graph of individuals of the principal component analysis) for:
A: Age groups
B: Sex groups
C: BMI groups 